\title{
From grammar to reading: a study on referential dependencies
}

\author{
Joana Batalha \\ Centro de Linguística da Universidade Nova de Lisboa ${ }^{\mathrm{i}}$
}

(Text received July 25 2019; accepted July 25 2019)

DOI: $\underline{\text { https://doi.org/10.5565/rev/jt13.811 }}$

\begin{abstract}
In this article, we present a study that investigated relations between grammar teaching and reading in Portuguese as mother tongue. The study, in which 91 students have participated, aimed at (i) pre-assessing students' ability to comprehend referential dependencies in reading at different stages (grade 4, 9-10 years old; grade 6, 11-12 years old; and grade 8, 12-13 years old), (ii) proposing a teaching intervention to develop language awareness about referential dependencies and, more specifically, to develop strategies to identify antecedents of pronouns (grade 4) and (iii) assessing the effects of the teaching intervention (grade 4). The study was based on a quasi-experimental methodology, with pre and posttests and a teaching intervention developed in the classroom, based on discovery-learning methods. Results of the study, which show positive effects of the teaching intervention, reinforce the benefits of grammar teaching as language awareness development. The study also offers a contribution towards the discussion of the role of grammar teaching to the development of late acquired structures, such as particular types of referential dependencies.
\end{abstract}

Keywords: language awareness, explicit knowledge of language, reading comprehension, referential dependencies, pronouns

Resumen: En este artículo, se presenta un estudio que investigó relaciónes entre la enseñanza de la gramática y la lectura en portugués como lengua materna. El estudio, en el que participaron 91 alumnos, tuvo como objetivos (i) pre-evaluar el conocimiento lingüístico de alumnos en diferentes niveles educativos (cuarto curso, 9-10 años; sexto curso, 11-12 años; e octavo curso, 12-13 años) en cuanto a la capacidad para comprender dependencias referenciales en la lectura, (ii) proponer una intervención didáctica para el desarrollo de la conciencia lingüística sobre dependencias referenciales y, más específicamente, para el desarrollo de estrategias de identificación de antecedentes de pronombres (cuarto curso) y (iii) evaluar los efectos de la intervención didáctica (cuarto curso). Basado en una metodologia cuasi experimental, el estudio se desarrolló con prueba previa y prueba posterior y una intervención didáctica, que siguió los métodos de aprendizaje por descubrimiento. Los resultados del estudio, que muestran los efectos positivos de la intervención didáctica, refuerzan los beneficios de enseñar la gramática como un desarrollo de la conciencia lingüística. El estudio también ayuda a mostrar el papel de la enseñanza de la gramática en las estructuras lingüísticas de desarrollo tardío, como ciertos tipos de dependencias referenciales.

Palabras clave: conciencia lingüística, conocimiento explícito de la lengua, comprensión de lectura, dependencias referenciales, pronombres 
Résumé : Dans cet article, nous présentons une étude sur les relations entre l'enseignement de la grammaire et la lecture en portugais langue maternelle. L'étude, à laquelle ont participé 91 étudiants, visait (i) à pré-évaluer la capacité des étudiants pour comprendre les dépendances référentielles en lecture à différents stades (4 ${ }^{\text {ème }}$ année, 9-10 ans ; $6^{\text {ème }}$ année, 11-12 ans; et $8^{\text {ème }}$ année, 12-13 ans), (ii) à proposer une intervention didactique pour développer la conscience linguistique sur les dépendances référentielles et, plus spécifiquement, sur l'élaboration de stratégies pour identifier les antécédents de pronoms ( $4^{\text {ème }}$ année) et (iii) à évaluer des effets de l'intervention didactique (4 ${ }^{\text {ème }}$ année). Basée sur une méthodologie quasi expérimentale, l'étude a été développée avec pré-test et post-test et une intervention didactique, qui a suivi les méthodes d'apprentissage par la découverte. Les résultats de l'étude, qui montrent les effets positifs de l'intervention didactique, renforcent les avantages de l'enseignement de la grammaire en tant que développement de la conscience linguistique. L'étude contribue également à montrer le rôle de l'enseignement de la grammaire dans les structures linguistiques en développement tardif, telles que certains types de dépendances référentielles.

Mots-clés: conscience linguistique, connaissance explicite sur la langue, compréhension en lecture, dépendances référentielles, pronoms

Resumo: Neste artigo, apresentamos um estudo que investigou relações entre ensino da gramática e leitura em português como língua materna. $\mathrm{O}$ estudo, no qual participaram 91 alunos, teve como objetivos (i) pré-avaliar o conhecimento linguístico de alunos em diferentes níveis de ensino (quarto ano, 9-10 anos; sexto ano, 11-12 anos; e oitavo ano, 12-13 anos) quanto à sua capacidade para compreender dependências referenciais na leitura, (ii) propor uma intervenção didática para o desenvolvimento da consciência linguística sobre dependências referenciais e, mais especificamente, para o desenvolvimento de estratégias de identificação de antecedentes de pronomes (quarto ano) e (iii) avaliar os efeitos da intervenção didática (quarto ano). Com uma metodologia quase experimental, o estudo foi desenvolvido através da aplicação de um pré-teste e de um pós-teste e incluiu uma intervenção didática, seguindo métodos de aprendizagem pela descoberta. Os resultados do estudo, que mostram efeitos positivos da intervenção didática, reforçam os benefícios do ensino da gramática para o desenvolvimento da consciência linguística. $\mathrm{O}$ estudo contribui ainda para evidenciar o papel do ensino da gramática no desenvolvimento de estruturas linguísticas adquiridas tardiamente, como certos tipos de dependências referenciais.

Palavras-chave: consciência linguística, conhecimento explícito da língua, compreensão da leitura, dependências referenciais, pronomes

Resumen: En aquest article, es presenta un estudi sobre les relacions entre l'ensenyament de la gramàtica i la lectura en portuguès com a llengua materna. L'estudi, en què van participar 91 alumnes, va tenir com a objectius (i) pre-avaluar el coneixement lingüístic d'alumnes en diferents nivells educatius (quart curs, 9-10 anys; sisè curs, 11-12 anys; i vuitè curs, 12 -13 anys) pel que fa a la capacitat per comprendre dependències referencials en la lectura, (ii) proposar una intervenció didàctica per al desenvolupament de la consciència lingüística sobre dependències referencials i, més específicament, per al desenvolupament d'estratègies d'identificació d'antecedents de pronoms (quart curs) i (iii) avaluar els efectes de la intervenció didàctica (quart curs). Basat en una metodologia quasi experimental, l'estudi es va desenvolupar amb prova prèvia i prova posterior i una intervenció didàctica, que va seguir els mètodes d'aprenentatge per descobriment. 
Els resultats de l'estudi, que mostren els efectes positius de la intervenció didàctica, reforcen els beneficis d'ensenyar la gramàtica com un desenvolupament de la consciència lingüística. L'estudi també ajuda a mostrar el paper de l'ensenyament de la gramàtica en les estructures lingüístiques de desenvolupament tardà, com certs tipus de dependències referencials.

Paraules clau: consciència lingüística, coneixement explícit de la llengua, comprensió lectora, dependències referencials, pronoms

\section{Introduction: Grammar teaching as language awareness development}

In the last two decades, in the Portuguese educational context, there has been a redefinition of the place of grammar in the curriculum of Portuguese as a mother tongue, which became evident with the adoption of the expression «explicit knowledge of language» to refer to grammar in official documents. According to the National Curriculum for Basic Education, which was in force between 2001 and 2011, «explicit knowledge of language» is defined as «a reflected, explicit and systematized knowledge of the units, rules and grammatical processes of language» (ME, 2001: 32). In 1997, a reference document for Portuguese language teaching (Sim-Sim, Duarte \& Ferraz, 1997) had already argued in favor of the development of explicit knowledge of language in grammar teaching, understood as the «progressive awareness and systematization of implicit knowledge in the use of language» (Sim-Sim, Duarte \& Ferraz, 1997: 31). From this perspective, language awareness is an intermediate level between the implicit, naturally acquired knowledge that every child possesses about their own language, and the explicit, reflected knowledge, which is dependent on metacognitive processes that are mainly developed with formal instruction, and which allows speakers to control the rules they use and to select the most adequate strategies when using language in communicative situations.

The adoption of «explicit knowledge of language» in official documents in Portugal (ME, 2001, 2009) was inspired by an Anglo-Saxon movement starting in the 1960s and 1970s that aimed at the integration of linguistics in school curricula, basically defending the idea that knowledge about language should be promoted in language teaching not only for instrumental purposes (i.e. because it is useful to spoken and written skills), but because language is considered an interesting object of study per se. In the 1990s, with the publication of Language Awareness in the Classroom (James \& Garrett, 1991) and the foundation of the Association for Language Awareness (ALA) in 1994, the term «language awareness» becomes popular and it is extended to other areas than language teaching, such as literature and translation. Some authors adopted equivalent terms to «language awareness». For instance, James \& Garrett (1991) refer to the relation between language awareness and «consciousness-raising»; Hudson (2008) 
mentions the term «knowledge about language» (KAL), designating «the explicit knowledge of facts and principles informed by the ideas of linguistics» (Carter, 1990 quoted by Hudson, 2008); Honda, O'Neil \& Pippin (2010) use the expression «linguistics literacy», emphasizing the scientific dimension of knowledge about mental grammar. In fact, language awareness methods are mainly inductive, typically involving students in small investigations about language.

The benefits claimed for language awareness development range across different dimensions, such as cognitive, affective and social dimensions (Duarte, 2008; Hudson, 2008; Garrett, 2013). Despite these benefits, the integration of this perspective in the curriculum has lurched back and forward ${ }^{\mathrm{ii}}$. In Essential Learnings, the most recent curricular document, it is clearly assumed that teaching grammar aims at the progressive development of language awareness and explicit knowledge of language. However, there is evidence that more traditional practices of grammar teaching are still dominant in Portuguese schools (Sim-Sim \& Rodrigues, 2006; R. Duarte, 2008; Ferreira, 2015). We also know that students' explicit grammatical knowledge is poorly developed during compulsory education (Ucha, 2007; Costa, 2008; IAVE 2017, 2018).

In this context, we present a study conducted to reinforce the benefits of grammar teaching as language awareness development. The study focusses particularly on the instrumental role of grammar, by investigating relations between language awareness and reading comprehension in a classroom context. It also offers a contribution towards the discussion of the role of grammar teaching to the development of late acquired structures, such as particular types of referential dependencies.

\section{The comprehension of referential dependencies}

The comprehension of referential dependencies is a relevant topic to study relations between language awareness and reading comprehension, particularly in young readers. In general terms, by referential dependency, we understand a type of anaphoric relation in which a given expression, the anaphoric expression, is referentially dependent of an antecedent expression to be interpreted (Halliday \& Hasan, 1976; Raposo, 1992; Lobo, 2013).

(1) I invited John to the party, but he did not accept my invitation. 
Anaphoric pronouns such as he in sentence (1) carry almost no intrinsic meaning, which means they need to take meaning from an antecedent as the nominal expression John.

The identification of an antecedent is dependent on different linguistic factors, such as the nature of the anaphoric expression and of the antecedent itself, the distance between pronoun and antecedent and the syntactic properties of the material inserted between the anaphoric expression and the antecedent.

Studies in language acquisition show that children have difficulties in understanding structures with referential dependencies in which the anaphoric expression is a pronoun. Linguistic properties such as the phonological form of the pronoun (strong or clitic) and its position in the sentence (subject or object) seem to play an important role. Some asymmetries regarding these properties were found in different languages, including in European Portuguese. For example, young children seem to have more difficulties in understanding relative pronouns in object position than in subject position and there is evidence that this asymmetry persists when children enter school (Costa et al., 2009; Costa, Lobo \& Silva, 2011).

In reading comprehension, referential dependencies are one of the linguistic mechanisms that operate at the integration level, which means they guide the integration of the meaning of sentences into larger units that allow the construction of a representation of the text. The identification of an antecedent may require the reader to use inferential processes, particularly when there is referential ambiguity, that is, when several entities may be potential antecedents. Additionally, comprehension of pronouns is an indicator that differentiates good and poor reading comprehenders (see Oakhill, Cain \& Elbro, 2015 for a review). For instance, children with poor comprehension levels are less able than same-age good comprehenders to identify the antecedent for a personal pronoun in a simple sentence and they are also less likely to supply the appropriate anaphoric expression in a cloze task (Oakhill \& Yuill, 1986).

\section{A study on referential dependencies}

\section{Hypotheses}

The main hypothesis of our study is that grammar teaching, understood as a means of developing students' language awareness, has positive effects on students' ability to interpret referential dependencies with pronouns. Particularly, three types of pronouns that occur in European Portuguese are studied:

(i) personal - third person variable pronouns ele (he), o (him), lhe (to him) and their morphological variants; 
(ii) demonstrative - invariable pronouns isso (that) and $o$ (that);

(iii) relative - invariable que (that).

The selected forms include strong and clitic personal and demonstrative pronouns; relative pronoun que was tested in subject and object positions. These pronominal forms differ in terms of the antecedent they refer to: antecedents of personal and relative pronouns are noun phrases, whereas demonstrative (invariable forms in particular) may have antecedents that are verbal phrases or sentences.

From this main hypothesis, specific hypotheses were formulated. While the first two $(\mathrm{H} 1-\mathrm{H} 2)$ are directly related to the main hypothesis of the study, i.e. the relations between language awareness of referential dependencies and comprehension of these structures in reading, hypotheses $\mathrm{H} 3-\mathrm{H} 5$ refer to linguistic factors that are relevant for the interpretation of referential dependencies, particularly to the identification of the antecedent of a pronoun, such as the nature of the pronoun and its properties, the distance between pronoun and its antecedent and the type of text in which the relation of referential dependency occurs.

Our hypotheses are the following:

- H1: if we assume that comprehension of referential dependencies is sensitive to linguistic development, we expect older students to perform better than younger students in tasks requiring the comprehension of pronouns and the identification of their antecedents;

- H2: if language awareness about referential dependencies and comprehension of these structures in reading are related, we predict that students with higher levels of language awareness will perform better in tasks requiring the comprehension of pronouns and the identification of their antecedents;

- H3: according to the linguistic properties of the pronouns selected for the study, we expect students to perform differently depending on the type of pronoun (personal, demonstrative and relative), its phonological form (strong or clitic) and its position in the sentence (subject or object);

- H4: if the distance between the pronoun and its antecedent is relevant to the identification of the antecedent, we expect students to perform differently depending on the location of the antecedent: the same simple or complex sentence, previous sentences and previous paragraphs;

- H5: if the type of text is relevant to the identification of the antecedent, we expect students to perform differently when reading narrative or expository texts. 


\section{Design of the study}

To test these hypotheses, we used a quasi-experimental design, with pre and posttests and a teaching intervention in the classroom. At the first stage, the pretest, we pre-assessed students' comprehension of referential dependencies in a reading task requiring the identification of antecedents of the different types of pronouns. At this stage, students in three different grades were tested (cf. Participants), since a developmental effect was expected.

At the second stage, a group of students in grade 4 (aged 9-10) participated in the teaching intervention as an experimental group. The teaching intervention, aimed at developing students' language awareness about formal properties of pronouns and their use in texts as anaphoric expressions, used discovery-learning methods (Bruner 1961; Hudson 1992), particularly the sequence of a grammar laboratory (Duarte, 1992, 2008; Costa et al., 2011). The main idea behind this type of method is that students are able to discover general patterns about language, based on the implicit knowledge they possess about their own language and making use of scientific reasoning. As Hudson (1992) puts it, discovery-learning assumes that «most of the data needed for a grammar lesson are already in the children's heads, so the teacher's role is mainly to guide them in exploring the patterns in the data and in gradually expanding their linguistic horizons» (Hudson, 1992: 10).

At the final stage (posttest), to assess the effects of the teaching intervention, the group of students that participated in the teaching intervention was tested again. As in the pretest, we used a reading task requiring the identification of antecedents of pronouns. The effects of the teaching intervention were assessed by comparing the results of the experimental group in both tests. Besides, results obtained by the experimental group in the pre and posttests were compared to those of a control group of students in the same grade, but that did not participate in the teaching intervention.

\section{Participants}

Convenience sampling was used to select the 91 students that participated in the study. The students were all L1 Portuguese speakers and did not have any identified cognitive or linguistic disorders. At the first stage of the study (pretest), there were three groups of participants: a group of 38 students in grade 4, aged 9-10; a group of 27 students in grade 6, aged 11-12; and a group of 24 students in grade 8, aged 12-13. At stage two (teaching intervention), students in grade 4 were divided into two groups: an experimental group with 20 students and a control group with 18 students. Finally, at stage three (posttest), students in grade 4 were tested again. 
Besides the groups of students, 12 adults (average age 31 years-old, Portuguese L1 speakers and graduate) also participated in the study as a control group, at the first and third stages of the study (pre and posttests).

\section{Materials and procedure}

For the pre and the posttests, two similar reading tasks were constructed. To complete the task, students had to read four texts in paper (two narrative and two expository texts) with an approximate extension (300 to 400 words each text) and the same average level of readability, measured by an automatic tooliii. Texts were chosen from authentic sources (books, press, Internet), but they were necessarily adapted to include the different types of pronouns considered. Besides the type of pronouns, other linguistic factors were tested: (i) the nature of the pronoun (strong or clitic) for personal and demonstrative pronouns and (ii) the syntactic position of the pronoun (subject or object) for relative pronouns; (iii) the distance between the pronouns and their antecedents, by looking into three different units (same sentence, previous sentence and same paragraph); (iv) the type of text (narrative or expository).

A total of forty short-answer items assessing the ability to identify the antecedents of the mentioned pronouns were constructed. Of the forty items, 21 assessed personal pronouns, 7 demonstrative and 11 relative pronouns. In each test, the first item was used as an example. To formulate the items, we used an indirect interrogative and avoided metalinguistic terms (such as «pronoun» or «antecedent»).

For the teaching intervention, four sets of materials were produced according to the grammar lab format (Duarte, 1992, 2008; Costa et al., 2011). Duarte (2008: 18-19) suggests that a grammar lab should be developed in seven steps: (i) it starts with a question or problem, based on linguistic data gathered by the teacher (for instance, selected from students' spoken or written production); (ii) children are guided to observe the data; (iii) students are asked to formulate hypotheses about the data, using previous intuitive linguistic knowledge; (iv) children manipulate the linguistic data to test the formulated hypotheses; (v) after an hypothesis is validated and confronted with new data, students are guided to register it as a conclusion or generalisation; (vi) children are then given opportunities to practice what they have learned; (vii) at the final step, learning is assessed in relation to the initial question or problem.

The teaching intervention implemented in our study started with a problem based on students' data that was collected in the pretest. Students were then guided to observe pronouns occurring in different linguistic units (as words, in sentences and in texts), to formulate 
hypotheses about the meaning of pronouns in these units and to draw conclusions about syntactic and semantic properties of pronouns: (i) an isolated pronoun has no meaning, so pronouns need an antecedent from which to get their meaning; (ii) anaphoric pronouns can have different types of antecedents - noun phrases, verbal phrases or even sentences, (iii) if a pronoun has gender and number marks, it has to agree with its antecedent.

Because the teaching intervention was designed to be more than a training for the reading tasks, materials included a diversity of tasks and formats, which demanded the activation of different cognitive strategies, even though they all involved the manipulation of linguistic structures at the level of identification of antecedents with anaphoric pronouns.

For instance, materials included tasks requiring the association between a pronoun and an antecedent, but also tasks in which the antecedent had to be discovered. In turn, within the activities aimed at the discovery of antecedents, the identification of the antecedent in an example such as John and Mary run the marathon. He loves running was required either directly - What does 'he' refer to? - or indirectly - Who loves running?. In addition, materials not only included paper and pencil tasks (in diverse formats - association, multiple choice, gap-fill, short-answer) but also ludic tasks, such as the games pronoun bingo and pronoun dominoes (Baumann \& Stevenson, 1986).

Pre and posttests were administered in paper and pencil format in the students' classrooms with the presence of the researcher and the teacher of the class. Before students started completing the test, brief instructions were given, and the example item was read aloud. Each student completed their test individually. Students in grades 6 and 8 took about sixty minutes to complete the test, whereas fourth graders needed approximately 75 minutes.

The pretest was administered during the first term and the posttest in the third term, at the end of the school year, approximately six months after the pretest. The teaching intervention was implemented in the second and third terms. It was conducted over six weeks, in five sessions of 45 minutes. The posttest was administered about six weeks after the end of the intervention.

The teaching intervention took place in the students' classroom with the presence of the researcher and the teacher of the class. In the first session, and because students were not familiar with the discovery-learning method, tasks were completed using a whole-class strategy. In the subsequent sessions, most of the tasks were completed individually and materials for self-correction were provided, alternating with teacher correction. Some of the tasks, 
particularly those designed for practising, such as the games, were performed in groups. The materials handed out in class were collected at the end of each session but were given back to the students.

\section{Results}

To analyse the data of the pre and posttests, items of the tests were scored one or zero points. Each test was scored by three experts and a V Cramer test was used, showing a strong association between each expert's scores. Statistical analysis was conducted using non-parametric test Pearson chi-squared in R. Results are considered statistically significant when $p$ value is $\leq 0,05$. Results are presented in this article based on the percentage of correct answers.

Starting with the linguistic factors that are relevant for the interpretation of referential dependencies, particularly to the identification of the antecedent of a pronoun (see $\mathrm{H} 3-\mathrm{H} 5)$, Figures 1 and 2 show results of the pretest for different types of pronouns and their properties (phonological form and position). As can be viewed in Figure 1, students' performance was sensitive to the type of pronoun and results show statistically significant differences between the pronouns for every group of students after multiple comparisons (personal vs demonstrative, demonstrative vs relative and relative vs personal): grade $4\left(X^{2}=201,0, X^{2}=71,8, X=6,6\right)$; grade $6\left(X^{2}=80,5, X^{2}=11,7, X^{2}=36,0\right)$; grade $8\left(X^{2}=101,7, X^{2}=32,6, X^{2}=14,3\right)$.

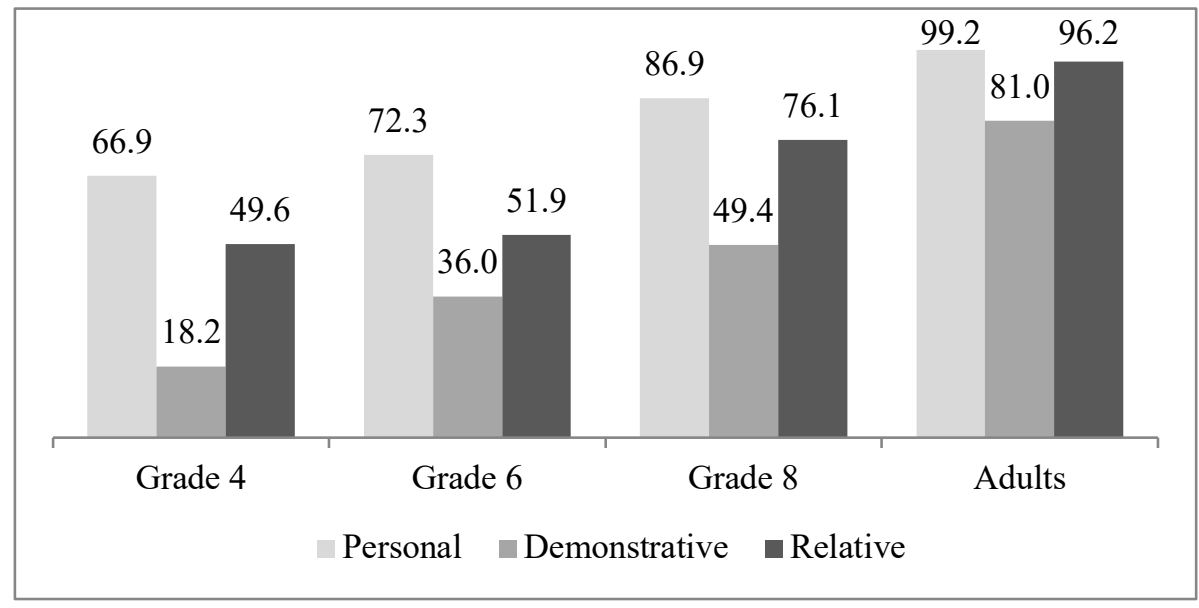

Figure 1. Percentage of correct answers in the pretest: type of pronoun

Regardless of their grade, students' results were lower with demonstrative pronouns, with percentages ranging from $18,2 \%$ in grade 4 to $49,4 \%$ in grade 8 among the students. Results for personal pronouns were the higher, with percentages ranging from $66,9 \%$ in grade 4 to $86,9 \%$ in grade 8 . It should be noted that fourth graders only achieve percentages above $50 \%$ 
with personal pronouns. Adults get percentages above $96 \%$ for personal and relative pronouns, but not for demonstratives.

In Table 1, we can observe statistically significant differences between (i) strong and clitic personal pronouns in the three groups of students: grade $4\left(X^{2}=29,8\right)$, grade $6\left(X^{2}=11,3\right)$, grade $8\left(X^{2}=6,7\right)$; and between (ii) subject and object relative pronouns in grade 4: $X^{2}=11,7$. These findings suggest that the phonological form and the position of the pronoun are relevant properties when students identify antecedents of pronouns.

Table 1. Percentage of correct answers in the pretest: properties of the pronouns

\begin{tabular}{|l|l|r|r|r|r|}
\hline \multicolumn{2}{|c|}{} & Grade 4 & Grade 6 & Grade 8 & Adults \\
\hline \multirow{3}{*}{ Personal } & Strong & $\mathbf{7 4 , 6}$ & $\mathbf{7 7 , 8}$ & $\mathbf{9 0 , 3}$ & 100 \\
\cline { 2 - 6 } & Clitic & $\mathbf{5 6 , 7}$ & $\mathbf{6 5 , 0}$ & $\mathbf{8 2 , 4}$ & 98,2 \\
\hline \multirow{3}{*}{ Demonstrative } & Strong & 21,9 & 42,6 & 40,6 & 70,8 \\
\cline { 2 - 6 } & Clitic & 13,4 & 27,2 & 61,1 & 94,4 \\
\hline \multirow{3}{*}{ Relative } & Subject & $\mathbf{5 5 , 7}$ & 52,9 & 77,4 & 98,8 \\
\cline { 2 - 6 } & Object & $\mathbf{3 8 , 8}$ & 50,0 & 74,0 & 91,7 \\
\hline
\end{tabular}

On the contrary, no statistically significant differences were found regarding the distance between the pronoun and its antecedent (Table 2). Multiple comparisons between the three units considered - same sentence, previous sentence and previous paragraph - only reveal statistically significant differences between the unit previous paragraph and the unit previous sentence in grade $8\left(X^{2}=7,5\right)$.

As for the type of text, data in Table 3 shows that students' performance was better with narrative texts than with expository texts, but statistically significant differences are only found in grades $4\left(X^{2}=6,1\right)$ and $6\left(X^{2}=11,3\right)$.

Table 2. Percentage of correct answers in the pretest: distance between pronoun and its antecedent

\begin{tabular}{|l|r|r|r|r|}
\hline & Grade 4 & Grade 6 & Grade 8 & Adults \\
\hline Same sentence & 53,0 & 56,0 & 78,7 & 96,9 \\
\hline Previous sentence & 54,1 & 64,8 & 80,0 & 98,8 \\
\hline Previous paragraph & 52,5 & 59,7 & $\mathbf{6 9 , 9}$ & 86,1 \\
\hline
\end{tabular}


Table 3. Percentage of correct answers in the pretest: type of text

\begin{tabular}{|l|r|r|r|r|}
\hline & Grade 4 & Grade 6 & Grade 8 & Adults \\
\hline Narrative texts & $\mathbf{5 5 , 9}$ & $\mathbf{6 4 , 3}$ & 78,9 & 96,0 \\
\hline Expository texts & $\mathbf{4 9 , 6}$ & $\mathbf{5 4 , 0}$ & 74,8 & 93,8 \\
\hline
\end{tabular}

Figure 2 displays global results of the pretest. A developmental effect is evident in the data presented; in other words, the results obtained are progressively higher according to the grade and age of the participants. Multiple comparisons between groups show statistically significant differences between the performance of (i) fourth and sixth graders $\left(X^{2}=11,6\right)$, fourth and eighth graders $\left(X^{2}=141,8\right)$ and fourth graders and adults $\left(X^{2}=269,8\right)$; (ii) sixth and eighth graders $\left(X^{2}=66,8\right)$ and sixth graders and adults $\left(X^{2}=192,8\right)$; (iii) eighth graders and adults $\left(X^{2}=71,6\right)$. This developmental effect is also evident when we look at each of the linguistic variables considered in the study: type of pronoun, properties of the pronoun, distance between pronoun and its antecedent and type of text (Figure 1 and Tables 1-3).

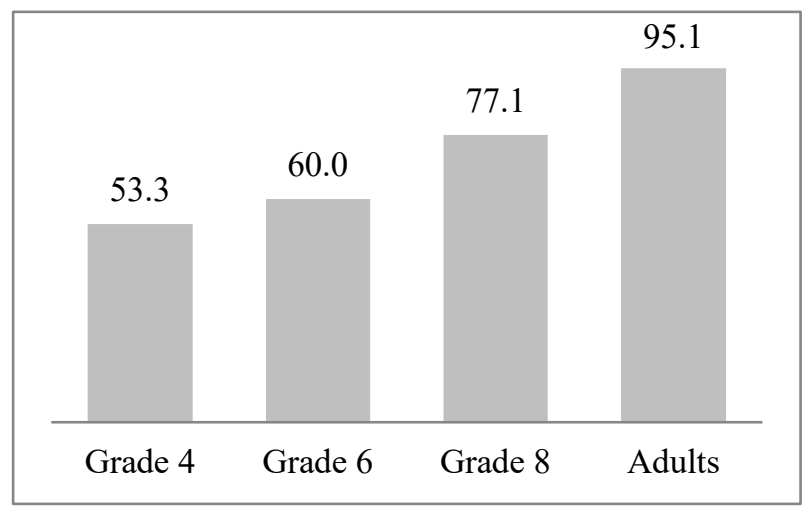

Figure 2. Percentage of correct answers in the pretest: global results per group

To assess the effects of the teaching intervention with the fourth graders, we compared the pre and posttests results of this group. We also compared the performance of the students in the experimental group to the students in the control group. As can be observed in the graph of Figure 3, the experimental group performs clearly better after the intervention and when compared to the control group. There are statistically significant differences between the pre and the posttests in each group, but Pearson chi-squared value found for the experimental group is much stronger: experimental $X^{2}=160,7$ vs control $X^{2}=8,7$. 


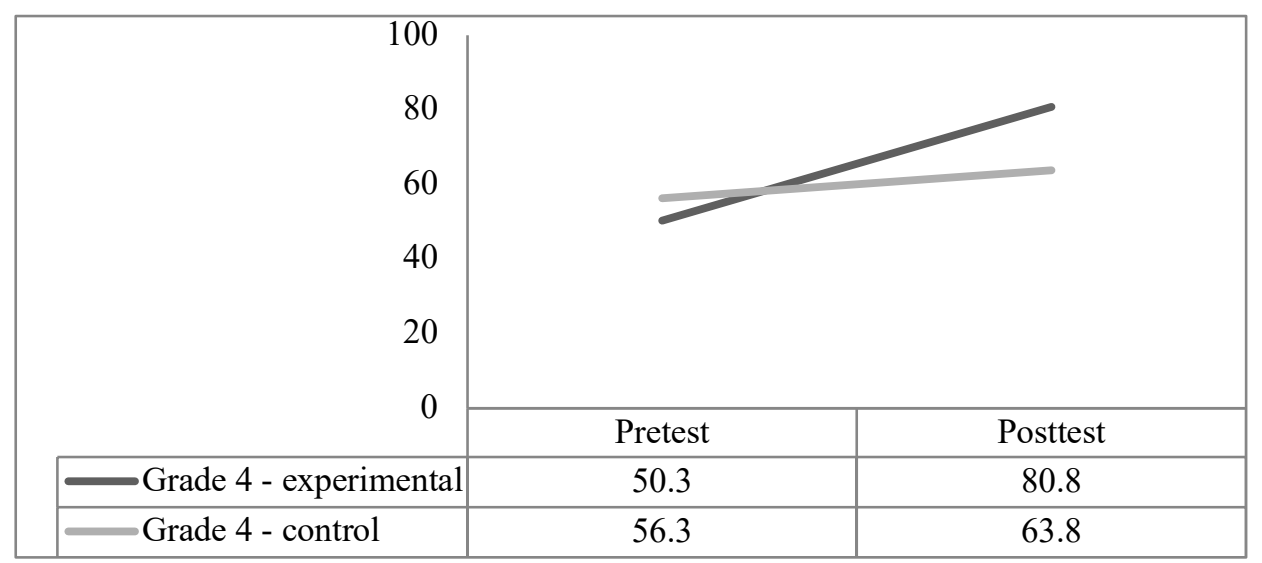

Figure 3. Percentage of correct answers in pre and posttests: global results per group

The same pattern is found when we analyse each of the linguistic variables of the study, i.e. students in the experimental group consistently performed better in the posttest. As an example, in Table 4, we can observe the differences between the pre and the posttests regarding the type of pronoun. These differences are statistically significant in the experimental group for the three types of pronouns: personal $\left(X^{2}=57,1\right)$, demonstrative $\left(X^{2}=84,8\right)$ and relative pronouns $\left(X^{2}=39,3\right)$.

Table 4: Percentage of correct answers in pre and posttests: type of pronoun

\begin{tabular}{|l|r|r|r|r|}
\hline \multirow{2}{*}{} & \multicolumn{2}{|c|}{ Experimental group } & \multicolumn{2}{c|}{ Control group } \\
\cline { 2 - 5 } & Pretest & \multicolumn{1}{c|}{ Postest } & Pretest & Postest \\
\hline Personal & $\mathbf{6 1 , 7}$ & $\mathbf{8 4 , 8}$ & 72,1 & 78,6 \\
\hline Demonstrative & $\mathbf{2 0 , 7}$ & $\mathbf{7 5 , 7}$ & $\mathbf{1 5 , 7}$ & $\mathbf{3 0 , 2}$ \\
\hline Relative & $\mathbf{4 7 , 3}$ & $\mathbf{7 6 , 4}$ & 51,8 & 57,0 \\
\hline
\end{tabular}

\section{Discussion}

The main hypothesis of our study is that grammar teaching, understood as a means of developing students' language awareness, has positive effects on students' ability to interpret referential dependencies with pronouns in reading. From this hypothesis, five specific hypotheses were formulated. While the first two $(\mathrm{H} 1-\mathrm{H} 2)$ are directly related to the main hypothesis of the study, i.e. the relations between language awareness of referential dependencies and comprehension of these structures in reading resulting from linguistic development and grammar teaching, hypotheses $(\mathrm{H} 3-\mathrm{H} 5)$ refer to linguistic factors that are relevant for the interpretation of referential dependencies (type of pronoun and its properties, distance between pronoun and its antecedent and the type of text).

We will discuss results obtained in the study based on each of these hypotheses: 
- H1: if we assume that comprehension of referential dependencies is sensitive to linguistic development, we expect older students to perform better than younger students in tasks requiring the comprehension of pronouns and the identification of their antecedents;

The prediction in $\mathrm{H} 1$ was confirmed. Considering the results of students in grades 4, 6 and 8 in the pretest, a developmental effect was observed. This effect, which seems to result from a combination of factors (linguistic development, processing capacities and level of instruction), suggests that comprehension of referential dependencies and, particularly, the ability to identify antecedents of pronouns is poorly developed in primary education and not completely consolidated by the end of basic ${ }^{\text {iv }}$ education.

- H2: if language awareness about referential dependencies and comprehension of these structures in reading are related, we predict that students with higher levels of language awareness will perform better in tasks requiring the comprehension of pronouns and the identification of their antecedents;

The prediction in $\mathrm{H} 2$ was confirmed. The positive effects of the teaching intervention were clearly shown in the results of the experimental group in the posttest and when we compared the performance of this group to the performance of a control group. Considering the topic of our study, referential dependencies, which we know plays an important role in reading comprehension, these results allow us to argue that language awareness can be developed in the classroom but also that higher levels of language awareness are useful for dealing with these structures in reading. We should note that results of the experimental group in the posttest improved more significantly with structures that were particularly difficult in the pretest (for example, demonstratives and object relatives).

- H3: according to the linguistic properties of the pronouns selected for the study, we expect students to perform differently depending on the type of pronoun (personal, demonstrative and relative), its phonological form (strong or clitic) and its position in the sentence (subject or object);

Predictions in $\mathrm{H} 3$ were partially confirmed. Results allows us to confirm that different pronouns are interpreted differently. In fact, a scale of difficulty was found in both tests and in all groups of participants: demonstrative pronouns were the most difficult, followed by relative and by personal pronouns, which were the less difficult. The fact that the demonstrative pronouns selected for the study typically refer to antecedents that are 
not nominal may explain the difficulties that most students and even adults found with these pronouns. Results for other properties, such as the phonological form and the position of the pronoun, were not as consistent. Nevertheless, more difficulties were found with clitic personal pronouns and with object relative pronouns, as found in other studies for European Portuguese.

- H4: if the distance between the pronoun and its antecedent is relevant to the identification of the antecedent, we expect students to perform differently depending on the location of the antecedent: the same simple or complex sentence, previous sentences and previous paragraphs;

Prediction in H4 was not confirmed, since no systematic effect of the factor distance was found. The most difficult units of distance for eighth graders were not the same as for fourth and sixth graders. For this reason, we argue that this factor operates additionally to other more relevant factors, such as the type of pronoun.

- H5: if the type of text is relevant to the identification of the antecedent, we expect students to perform differently when reading narrative or expository texts.

This prediction was partially confirmed. Although the quantitative analysis suggests that students' performance in the tasks was sensitive to the type of text, this was not found in all the groups of participants and no systematic relation between items with lower percentages and expository texts was observed.

\section{Final remarks}

Since 2018, Essential Learnings have officially become the main curricular reference for compulsory education in Portugal. In the domain of Portuguese as mother tongue, this document readopts a perspective of grammar teaching as the development of language awareness and progressive explicit knowledge about language. In Essential Learnings for grade 1, for example, we can read that «in the domain of grammar, the first cycle of basic education will allow students to develop their language awareness, by consolidating progressively the ability to reflect upon language and to control the rules that structure language and its use» (ME, 2018: 3).

In this context, data obtained in the study may be particularly relevant to reinforce the evidence of the role of grammar to the development of language use skills, by showing that awareness and explicit knowledge about language, promoted by discovery-learning methods, are positively related to reading skills. This finding is particularly relevant to the definition of reading strategies that consider properties of the linguistic structures used in texts. On the other 
hand, the study contributes to the identification of language structures of late development, i.e. structures (such as relative sentences with object pronouns) that are not consolidated when students enter school. The identification of these structures is fundamental for a grammar teaching that considers stages of linguistic development at the time of selecting topics to be taught and teaching strategies.

In the end, we are not far from old questions in grammar teaching: «what to teach?», «how to teach?» and «why to teach».

\section{References}

Batalha, J. (2017). Relações entre conhecimento explícito da língua e a competência de leitura. Compreensão de dependências referenciais no ensino básico. Tese de Doutoramento em Linguística e Ensino de Língua apresentada à Universidade Nova de Lisboa.

Baumann, J. F. \& J. Stevenson (1986). Teaching students to comprehend anaphoric relations. In J. Irwin (ed.). Understanding and teaching cohesion comprehension. Newark, DE: International Reading Association.

Bruner, J. (1961). The act of discovery. Harvard Education Review, 31, 21-32.

Costa, J. (2008). Conhecimento gramatical à saída do Ensino Secundário: estado actual e consequências na relação com leitura, escrita e oralidade. In C. Reis (org.). Actas da Conferência Internacional sobre o Ensino do Português. Lisboa: DGIDC-ME, 149-165.

Costa, J., A. Cabral, F. Viegas \& A. Santiago (2011). Conhecimento Explícito da Língua. Guião de Implementação do Programa. Lisboa: DGIDC-ME.

Costa, J., M. Lobo, C. Silva \& E. Ferreira (2009). Produção e compreensão de orações relativas em Português Europeu: dados do desenvolvimento típico, de PEDL e do agramatismo. In Textos Seleccionados, XXIV Encontro Nacional da APL. Lisboa: APL, 211-224.

Costa, J., M. Lobo, C. Silva (2011). Subject-object asymmetries in the acquisition of Portuguese relative clauses: Adults vs. children. Lingua, 121, 1093-1100.

Duarte, I. (1992). Oficina gramatical: contextos de uso obrigatório de conjuntivo. In DelgadoMartins et al. Para a Didáctica do Português. Seis Estudos de Linguística. Lisboa: Colibri.

Duarte, I. (2008). O Conhecimento da Língua: Desenvolver a Consciência Linguística. Lisboa: PNEP. DGIDC-ME.

Duarte, R. (coord.) (2008). Posição dos docentes relativamente ao ensino da Língua Portuguesa. Lisboa: DGIDC-ME. 
Ferreira, P. (2015). Ensino da gramática: conceções, práticas, currículo e terminologia. In S. Pereira, M. Rodrigues, A. Almeida, C. Pires, C. Tomás \& C. Pereira (orgs.). Atas do II Encontro de Mestrados em Educação da Escola Superior de Educação de Lisboa, Lisboa: CIED, 153-163.

Garrett, P. (2013). Language awareness. In M. Byram \& A. Hu (eds.). Routledge Enclyclopedia of Language Teaching and Learning, 2nd edition. Abingdon, Oxon: Routledge, 383386.

Halliday, M. A. K. \& R. Hasan (1976). Cohesion in English. London: Longman Group.

Honda, M., W. O’Neil \& D. Pippin (2010). On promoting linguistics literacy: Bringing language science to the English classroom. In Denham, K. and Lobeck, A. (eds.). Linguistics at school: Language awareness in primary and secondary education. Cambridge: Cambridge University Press, 175-188.

Hudson, R. (1992). Teaching Grammar. A Guide for the National Curriculum. Oxford: Blackwell.

Hudson, R. (2008). Linguistic Theory. In B. Spolsky e F. M. Hult (eds.) The Handbook of Educational Linguistics. Oxford: Blackwell, 53-65.

Instituto de Avaliação Educacional (2018). Resultados nacionais das provas de aferição -2018. IAVE-ME.

Instituto de Avaliação Educacional (2017). Resultados nacionais das provas de aferição 2016/2017. IAVE-ME.

James, C. \& P. Garrett (eds.) (1991). Language Awareness in the Classroom. London/New York: Longman.

Lobo, M. (2013). Dependências referenciais. In E. B. P. Raposo, M. F. B. Nascimento, M. A. C. Mota, L. Segura \& A. Mendes (orgs.). Gramática do Português. Volume II. Lisboa: Fundação Calouste Gulbenkian, 2177-2227.

Ministério da Educação (2001). Currículo Nacional do Ensino Básico. Competências Essenciais. DEB-ME.

Ministério da Educação (2009). Programas de Português para o Ensino Básico. Lisboa: DGIDC-ME.

Ministério da Educação (2015). Programas e Metas curriculares de Português. Lisboa: DGEME.

Ministério da Educação (2018). Aprendizagens Essenciais - Português. Lisboa: DGE-ME. 
Oakhill, J. \& N. M. Yuill (1986). Pronoun resolution in skilled and less skilled comprehenders: Effects of memory load and inferential complexity. Language and Speech, 29, 25-37.

Oakhill, J., K. Cain \& C. Elbro (2015). Understanding and Teaching Reading Comprehension. A handbook. New York: Routledge.

Raposo, E. P. (1992). Teoria da Gramática. A Faculdade da Linguagem. Lisboa: Editorial Caminho.

Sim-Sim, I. \& P. Rodrigues (2006). O ensino da gramática visto por professores e alunos. In I. Sim-Sim (coord.). Ler e ensinar a ler. Porto: Edições ASA, 125-138.

Sim-Sim, I., I. Duarte \& M. J. Ferraz (1997). A Língua Materna na Educação Básica. Lisboa: DEB-ME.

Ucha, L. (coord.) (2007). Desempenho dos alunos em língua portuguesa - ponto da situação. Lisboa: DGIDC-ME.

\footnotetext{
${ }^{\mathrm{i}}$ The study presented in this article was developed as a PhD research project funded by the Foundation for Science and Technology (individual grant SFRH/BD/73881/2010), supervised by Professors João Costa and Ana Luísa Costa. The project resulted in the $\mathrm{PhD}$ thesis «Relations between explicit knowledge of language and reading skills. Comprehension of referential dependencies in basic education» (Batalha, 2017).

${ }^{\text {ii }}$ We refer to the changes occurred between 2011 and 2015 that led to the cancellation of the National Curriculum and to the publication of the Programs and Curricular Goals (ME, 2015), which did not adopt this perspective, but a traditional perspective of grammar teaching. Although it is argued in the document that metalinguistic awareness should start and develop in the first cycle of education (ME, 2015: 8), grammar learning is viewed as fundamentally based on memorization of rules and classification of linguistic units, as concluded by Batalha (2017) in an analysis about pronouns.

iii The tool used was the LX-CEFR, a free software created by the Lx-Center, Language Resources and Technology for Portuguese.

${ }^{\text {iv }}$ Basic education in Portugal includes three cycles: grades 1-4 in cycle 1, grades 5-6 in cycle 2 and grades 7-9 in cycle 3.
}

\begin{abstract}
Authors' information
Joana Batalha holds a PhD in Linguistics and Language Teaching. She is a researcher of the Linguistics Research Centre of NOVA University Lisbon (CLUNL) and Invited Assistant Professor in the Faculty of Social and Human Sciences at NOVA University Lisbon. She has participated in research projects in L1 and L2 acquisition and in different areas of Portuguese teaching, such as curricular development, teacher development and language assessment. She has been a teacher and has collaborated with the Ministry of Education and the Camões Institute. E-mail: jbatalha@fcsh.unl.pt
\end{abstract}

To cite this article:

Batalha, J, (2019). From grammar to reading: a study on referential dependencies. Bellaterra Journal of Teaching \& Learning Language \& Literature 12(2), 60-77. DOI: https://doi.org/10.5565/rev/jt13.811

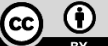

